\title{
Foreign Trade in the Kaliningrad Region in 2000-2014, Growth Rates, Structure and Prospects
}

\author{
Oleg N. Bolychev \\ Lidia G. Osmolovskaya* \\ Yury M. Zverev \\ Immanuel Kant Baltic Federal University, Russian Federation \\ *Corresponding Email: LOsmolovskaya@kantiana.ru
}

\section{Doi:10.5901/mjss.2015.v6n6s7p257}

\begin{abstract}
The article discusses the dynamics, commodity structure and geography of the Kaliningrad region's foreign trade since 2000. It has been shown that a free customs zone regime, which was established in the framework of a special economic zone (SEZ) in the Kaliningrad region with the import-substituting economy producing for the Russian market based thereon, has the key impact on the dynamics and structure of trade. At the same time, exports from the region, which reached the peak in 2007, have not returned to the same volume. Given are some suggestions concerning the improvement of the Kaliningrad region's foreign trade in the changed geopolitical context.
\end{abstract}

Keywords: Russia, Kaliningrad region, Special Economic Zone, SEZ, foreign trade, exports, imports

\section{Introduction}

Since 1991, after the establishment in Kaliningrad of the Free Economic Zone (FEZ) Yantar, the region began to operate in the mode of a free customs zone. Adopted on 22 January 1996 the federal law 'On the Special Economic Zone in the Kaliningrad region' preserved customs privileges.

In accordance with the new federal law 'On the Special Economic Zone in the Kaliningrad Region and on Amendments to some Regulatory Instruments of the Russian Federation' dated 10 January 2006, the free customs zone shall be maintained for a ten-year transition period (until 1 April 2016) for legal entities that carry out their activities in accordance with the 1996 federal law.

Typically, the free/special economic zones (FPZs/SEZs) are oriented outwards to encourage the export of finished products. Increased export orientation of the Kaliningrad region has also been considered and treated as one of the strategic lines of development of the exclave region of Russia. In this paper, we examine how the FEZ/SEZ regime affected the dynamics, geography and structure of foreign trade in the Kaliningrad region ${ }^{1}$ and what the possible ways of improving the foreign trade are. The 2000th year, which had been the first year of economic recovery completing the transition period crisis, was selected as the starting point of the analysis. You can see more detail about the peculiarities of the region's foreign economic relations in the 1990s in the works of Fedorov and Zverev (2002), Khlopetsky and Fedorov (2000), Klemeshev et al. (2002), Zverev $(2004,2009)$.

\section{External Trade Growth}

The FEZ/SEZ mode contributed to the rapid and steady growth of the Kaliningrad region's foreign trade turnover. Some exceptions were only in 1998 - 1999 because of the effects of the financial crisis in August 1998 (Table 1, Fig. 1).

\footnotetext{
${ }^{1}$ The article deals only with trade in goods. Foreign trade in services, due to its small volume and a lack of statistical data, remains outside of our analysis.
} 
Table 1. Dynamics of exports and imports of goods of the Kaliningrad region, $2000-2014$ (\$ million)

\begin{tabular}{ccccc}
\hline Year & Export & Import & Turnover & Balance \\
\hline 2000 & 475.2 & 874.7 & 1349.9 & -399.5 \\
2001 & 455.3 & 1046.7 & 1502.0 & -591.4 \\
2002 & 470.6 & 1610.1 & 2080.7 & -1139.5 \\
2003 & 573.8 & 2141.9 & 2715.7 & -1568.1 \\
2004 & 1174.8 & 3132.8 & 4307.6 & -1958.0 \\
2005 & 1825.6 & 4077.1 & 5902.7 & -2251.5 \\
2006 & 2545.7 & 5372.7 & 7918.4 & -2827.0 \\
2007 & 5119.5 & 7952.2 & 13071.7 & -2832.7 \\
2008 & 1121.5 & 9620.0 & 10741.5 & -8498.5 \\
2009 & 718.8 & 5326.9 & 6045.7 & -4608.1 \\
2010 & 716.8 & 8076.8 & 8793.6 & -7360.0 \\
2011 & 1379.6 & 10469.4 & 11849.0 & -9089.8 \\
2012 & 1948.6 & 12251.5 & 14200.1 & -10302.9 \\
2013 & 1600.0 & 12356.7 & 13956.7 & -10756.7 \\
2014 & 3549.0 & 15681.8 & 19230.8 & -12132.8 \\
\hline
\end{tabular}

Source: compiled by the author based on the Kaliningrad Region in Figures, ; Kaliningrad Region in Figures, 2009; Kaliningrad Region in Figures, 2014; Foreign trade of the Kaliningrad Region as of January-December 2014, 2015.

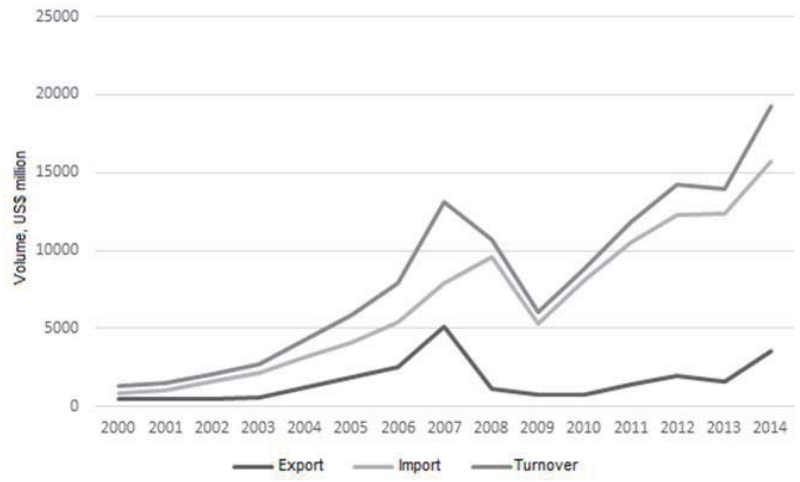

Figure 1. Dynamics of foreign trade of the Kaliningrad region, as a percentage of 2000

Source: compiled by the author based on the Kaliningrad Region in Figures. 2005; Kaliningrad Region in Figures, 2009; Kaliningrad Region in Figures, 2014; Foreign Trade of the Kaliningrad Region as of January-December 2014, 2015.

In 2000 - 2014 the Kaliningrad region's foreign trade turnover (goods) increased by 14.2 times (in current prices).

The exports of goods were growing rapidly in 2000-2007 with an increase by10.8 times over that period. In 20082010 there was a sharp decline (down by 7.1 times compared to 2007). Since 2011, growth had resumed but then there was another recession in 2013. As a result, the exports of goods increased by 7.5 times in 2000-2007, or the growth was almost twice lower than in the foreign trade turnover. Thus, in absolute terms exports have failed to reach the maximum level of 2007.

The growth of imports of goods in 2000-2007 was somewhat slower than exports (growth by 9.1 times). Then there was a decline but later (in 2009); it was shorter and not as sharp as in the case of exports (reduction by 1.8 times in 2008-2009). Then imports again began to grow having increased in 2010-2014 by almost 3 times. Overall, the imports of goods increased by almost 18 times in 2000-2014.

The region's proportion in Russia's foreign trade in goods increased in $2000-2014$, in the foreign trade turnover from 0.9 to $2.4 \%$, in export from 0.45 to $0.7 \%$ (the maximum share during that period was in 2007, i.e. $1.5 \%$ ), in imports from $1.9 \%$ to $5.1 \%$ (calculated by the Kaliningrad Region in Figures, 2005; Kaliningrad Region in Figures, 2009; Kaliningrad Region in Figures, 2014; Kaliningrad Region's Foreign Trade in January-December 2014, 2015, Foreign Trade in Goods of the Russian Federation, 2015). 


\section{Foreign Trade Deficit and Its Origin}

A feature peculiar to the Kaliningrad region's foreign trade is a trade deficit amounting to more than $\$ 12$ billion in 2014 as far as goods and services are concerned. However, it should be borne in mind that a significant portion of imports, which represents the main part in some product categories, is ultimately shipped to other regions of Russia or used for the production of import-substituting products in the SEZ regime for the Russian market. The current trade deficit of the region thus characterises its place in a national division of labour, i.e. the imports to other regions of Russia and the production of import-substituting products for other Russian regions. Nevertheless, you cannot state that issue of transformation of the regional economy towards export orientation, which has been repeatedly addressed in the regional development strategies, is tackled poorly despite the region's share in the Russian exports of goods being $0.7 \%$ exceeds its share in the total GRP the Russian Federation (0.5\%).

\section{Commodity Structure of the Kaliningrad Region's Foreign Trade}

The commodity structure of the Kaliningrad region's export is better than that of Russia as a whole. If the Russian export structure is dominated by mineral products $(71.5 \%$ of exports in 2013), the leading export items of the Kaliningrad region are engineering products accounting for $61.2 \%$ of the total value of exports in 2014 (machinery, equipment and vehicles account for only 5.5\% of exports in Russia as a whole) (Kaliningrad Region's Foreign Trade Results..., 2015; Russian Statistical Yearbook, 2014 p. 606) (Table 2). At the same time, as far back as $200677.4 \%$ of exports accounted for products of the fuel-and-energy sector, while the share of machinery products accounted for only $11.2 \%$ (Report.... , 2007).

Table 2. Commodity structure of the Kaliningrad region's exports in 2014

\begin{tabular}{lcc}
\hline Commodity group & In US\$ million & In \% \\
\hline Machinery and mechanical appliances; parts thereof & 1468.0 & 41.4 \\
Electrical machinery and equipment, parts thereof & 703.5 & 19.8 \\
Fats and oils of the animal or vegetable origin & 439.7 & 12.4 \\
Residues and waste from the food industry, animal feed & 317.9 & 9.0 \\
Cereals & 170.3 & 4.8 \\
Mineral fuels, mineral oils and products thereof & 89.3 & 2.5 \\
Ferrous metals & 45.4 & 1.3 \\
Fertilisers & 37.0 & 1.0 \\
Wood and wood articles; charcoal & 35.6 & 1.0 \\
Oil seeds and fruits & 31.0 & 0.9 \\
Other & 211.3 & 5.9 \\
\hline Total & 3549.0 & 100.0 \\
\hline
\end{tabular}

Source: compiled by the author based on the Kaliningrad Region's Foreign Trade Results for January-December 2014 (2015).

A significant part of the Kaliningrad region's imports (Table 3) accounts for industrial goods (components for the assembly of cars, liquid crystal devices, parts and components for the television and video equipment etc.). This is due to the presence in the Kaliningrad region of import substitution industries operated on imported parts (the car assembly plant of JSC Avtotor, a joint-stock company and several plants for the assembly of television and video equipment and the electronics industry innovation cluster Technopolis GS). Import-substituting industries are related to the import of oilseeds and fruits (for UAB Sodruzhestvo-Soya, Soyuz-TTM Ltd), furniture parts (for about 200 organisations and individual entrepreneurs without a legal entity in the furniture industry), copper (for Baltic-Cable Ltd and others) and the bulk of meat (for about 70 meat processing plants).

Table 3. Commodity structure of the Kaliningrad region's imports in 2014

\begin{tabular}{lcc}
\hline Commodity group & In US\$ million & In \% \\
\hline Electrical machinery and equipment, their parts & 3765.3 & 24.0 \\
Vehicles for land transport & 2902.9 & 18.5
\end{tabular}




\begin{tabular}{lcc} 
Machinery and mechanical appliances, their parts & 2619.9 & 16.7 \\
Oil seeds and fruits & 1113.1 & 7.1 \\
Meat and edible offal & 591.7 & 3.8 \\
Copper and articles thereof & 415.1 & 2.6 \\
Furniture; bedding items & 348.2 & 2.2 \\
Paper and paperboard; articles thereof & 297.6 & 1.9 \\
Plastics and articles thereof & 283.7 & 1.8 \\
Fish, crustaceans, molluscs and other aquatic invertebrates & 230.9 & 1.5 \\
Other & 3113.2 & 19.9 \\
\hline Total & 15681.8 & 100.0 \\
\hline
\end{tabular}

Source: compiled by the author based on the Kaliningrad Region's Foreign Trade for January-December 2014 (2015).

\section{The Kaliningrad Region's Foreign Trade Geography}

In 2014 the Kaliningrad region's importers/exporters were trading with 156 countries of the world. Moreover, the Kaliningrad region is characterised by the absolute predominance of foreign countries in terms of the geographical structure of foreign trade. Their share in the foreign trade turnover in 2014 amounted to $98.7 \%$ and only $0.3 \%$ accounted for the CIS countries (in 2000 their share was 10.1\%) (Kaliningrad Region's Foreign Trade Results for January-December 2014 (2015), Kaliningrad Region in Figures 2004 (2004, 115).

Back in 2000, about $47 \%$ of the Kaliningrad region's foreign trade (commodity) turnover accounted for Poland, Germany and Lithuania. By 2014, their share dropped to $17.2 \%$, with Poland and Lithuania now ranking only $7^{\text {th }}$ and $11^{\text {th }}$ (in 2000, $1^{\text {st }}$ and $3^{\text {rd }}$ respectively). Now the Kaliningrad region's three leading partners in the trade in goods are China, South Korea and Germany. But their share (40.1\%) is lower than that of Poland, Germany and Lithuania in 2000 (Foreign Economic Activities of the Kaliningrad Region's Companies and Organisations in 2000-2007 (2008), Kaliningrad Region's Foreign Trade Results for January-December 2014 (2015)). That is the foreign trade of the Kaliningrad region in geographical terms became more differentiated but now $82.2 \%$ of the foreign trade still accounts for only 13 countries (Table 4).

Table 4. The geographical structure of the Kaliningrad region's foreign trade in 2014

\begin{tabular}{lc}
\hline Country & The share of foreign trade turnover (in \%) \\
\hline China & 19.4 \\
Republic of Korea & 10.4 \\
Germany & 10.3 \\
United Kingdom & 7.5 \\
Slovakia & 6.9 \\
United States & 4.8 \\
Poland & 4.6 \\
Brazil & 4.3 \\
Paraguay & 3.6 \\
Estonia & 3.5 \\
Switzerland & 2.5 \\
Lithuania & 2.3 \\
Thailand & 2.1 \\
Others & 17.8 \\
\hline Total & 100.0 \\
\hline
\end{tabular}

Source: compiled by the author based on the Kaliningrad Region's Foreign Trade Results for January-December 2014 (2015).

\section{Key Directions of Improvement of the Kaliningrad Region's Foreign Trade}

The main areas of improvement of the Kaliningrad region's foreign trade can include as follows:

- strengthening the production's focus on export by increasing the exports of products with higher added value;

- fuller use of the region's potential as one of the main import channels in the national market; 
- the increased importance of the region in servicing the external relations in the CIS countries, primarily Belarus and Kazakhstan.

- further diversification of the region's foreign trade relations due to the increased attention to areas such as the United States, Latin America, Africa, Southeast Asia.

The EU Enlargement on 1 May 2004 has objectively impeded access for the Kaliningrad products to the national market and the supply of raw materials to the region. For that reason and due to the fact that the new development strategy of the Kaliningrad region provides for its integration as a part of Russia in the Baltic region, and the export orientation of the economy will be enhanced. In this connection, some measures to encourage exports are essential. Among the priority measures in this area, the following can be offered: 1) To permanently monitor the social and economic processes in the Baltic region, especially in the neighbouring countries (Poland and the Baltic countries) with the involvement of the I. Kant BFU. 2) To make a research paper to review the external economic potential of the region and determine its prospects for development, and on that basis prepare and adopt a regional export incentive programme. 3) To develop and adopt a targeted programme for training and retraining of personnel engaged in the foreign economic activities (in the premises of the I. Kant BFU). 4) To create in Kaliningrad region the Export Support Centre with the input from federal and regional ministries and departments as well as the Regional Export Council bringing together the leading regional exporting companies. 5) To create the Product and Service Certification Centre meeting the EC standards. 6) To promote the establishment of special institutions for lending to smaller exporters; 7) To arrange for awarding the best exporter of the year demonstrating outstanding results; 8) To follow up the development of small business centres providing the technical and business advice to small and medium enterprises and allowing them to compete in international markets and introduce modern technologies. To render individual consulting to exporters and hold seminars and conferences; 9) To establish in the Kaliningrad region a large multi-purpose exhibition and business centre Euro-EXPO in order to demonstrate business proposals to potential investors and trade partners of the Russian regions and hold a large-scale investment congress (the idea by S.V. Kortunov).

\section{References}

Fedorov, G.M., \& Zverev, Yu.M. (2002). Social and Economic and Geopolitical Development of the Kaliningrad Region: Tutorial. Kaliningrad. Publishers of the Kaliningrad State University.

Foreign Trade Activities of the Kaliningrad Region's Companies and Organisations in 2000-2007 (2008). Summary Statistical Book. Kaliningrad. Territorial Body of the Federal State Statistics Service in the Kaliningrad Region.

Foreign Trade in Goods of the Russian Federation (2015) The Bank of Russia. [Online] Available: http://www.cbr.ru/statistics/credit_ statistics/print.aspx?file=trade.htm (August 05, 2015).

Kaliningrad Region in Figures. 2004 (2004). Short Statistical Book. Territorial Body of the Federal State Statistics Service in the Kaliningrad Region. - Kaliningrad.

Kaliningrad Region in Figures. 2005 (2005). Short Statistical Book. Territorial Body of the Federal State Statistics Service in the Kaliningrad Region. Kaliningrad.

Kaliningrad Region in Figures. 2009 (2009). Short Statistical Book Territorial Body of the Federal State Statistics Service in the Kaliningrad Region. Kaliningrad.

Kaliningrad Region in Figures. 2014 (2014). Statistical Book in 2 volumes / Territorial Body of the Federal State Statistics Service in the Kaliningrad Region. Kaliningrad.

Kaliningrad Region's Foreign Trade Results for January-December 2014 (2015) Kaliningrad Regional Customs Authority. [Online] Available: http://koblt.customs.ru/attachments/article/19367/Калининград-2014г..doc (August 05, 2015).

Khlopetsky, A.P., \& Fedorov, G.M. (2000). Kaliningrad Region, a Region of Cooperation: Monograph. Kaliningrad: Yantarny Skaz (Amber Tale).

Klemeshev, A.P., \& Kozlov, S.D., \& Fedorov, G.M. (2002). Isle of Cooperation: Monograph. Kaliningrad: Publishers of the KSU.

Report (2006). Report on the Results of Operation of the Special Economic Zone in the Kaliningrad Region in $2006 . \quad$ The Special Economic Zone Administration in the Kaliningrad Region.

Russian Statistical Yearbook (2014). Statistical Book /Rosstat (Russian Federal State Statistics Service). M.

Zverev, Yu.M. (2004). Russian Baltika, Cross-Border Cooperation. In: Cross-Border Economic Cooperation, Foreign Trade of the Kaliningrad Region. A.P. Klemeshev (ed.). (pp.17-28). Kaliningrad: Publishers of the KSU.

Zverev, Yu.M. (2009). Foreign Trade in the Kaliningrad Region: Main Trends. Newsletter of the Immanuel Kant Russian State University. Issue 3. Ser. Economic and Legal Sciences (pp. 70-74). Kaliningrad: Publishers of the I. Kant RSU. 